\title{
Unsettling the Colonial Linear Perspective in Kim Scott's Benang
}

Anne Le Guellec

\section{(2) OpenEdition \\ 1 Journals}

Electronic version

URL: https://journals.openedition.org/ces/8294

DOI: $10.4000 /$ ces.8294

ISSN: 2534-6695

Publisher

SEPC (Société d'études des pays du Commonwealth)

\section{Printed version}

Date of publication: 1 September 2010

Number of pages: $35-44$

ISSN: 2270-0633

\section{Electronic reference}

Anne Le Guellec, "Unsettling the Colonial Linear Perspective in Kim Scott's Benang", Commonwealth Essays and Studies [Online], 33.1 | 2010, Online since 11 December 2021, connection on 20 January 2022. URL: http://journals.openedition.org/ces/8294 ; DOI: https://doi.org/10.4000/ces.8294

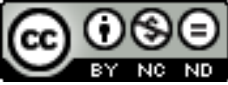

Commonwealth Essays and Studies is licensed under a Licence Creative Commons Attribution - Pas d'Utilisation Commerciale - Pas de Modification 4.0 International 


\section{Unsettling the Colonial Linear Perspective in Kim Scott's Benang}

At the end of the $19^{\text {th }}$ and the beginning of the $20^{\text {th }}$ century, social Darwinism in Australia gave scientific legitimacy to the colonial representation of the Aborigines as the "dying race." The "half-caste" himself was described as a mere "passing phase" in the history of white conquest. This paper will focus on how Kim Scott undertakes in his novel Benang (1999) to subvert the simplistic, destructive and ultimately self-defeating doctrine of progress championed by colonists whose eugenicist policies aimed at "breeding out" the Aboriginal heritage. Scott shows how pioneering megalomania drove those white visionaries of the future Australian race to aspire to being their own beginning and their own end. To counter this colonial narrative which maps out progress as a process of purification, and posits sameness as the only desirable goal on the national horizon, he deploys a circuitous and ultimately circular exploration of time and space. This narrative is informed both by the memories of his narrator's Aboriginal relatives and by the narrator's imaginative empathy with his ancestors, which eventually enables him to substitute a pattern of return and permanence for the narcissistic and misguided abstraction of linear progress.

W 1th the age of the great explorations and discoveries in the natural sciences, the horizon ceased to be perceived by the Western consciousness as a boundary hemming in the known world, and became, rather, an invitation to explore and to conquer. Significantly, the horizon, as signifying limitless yet dynamic space, would later also be used as a metaphor for modern historical time, freed from the circularity of tradition and religion, and confident in linear progress. As Erwin Panofsky has shown in his famous essay Perspective as Symbolic Form, the invention of the linear perspective in the first half of the $15^{\text {th }}$ century led to a new relationship between the subject and the world. Although the point of view from which perspective is constructed remains subjective, its projections are transcribed mathematically, and thus rationalized. According to Panofsky, the "objectification of the subjective" which the new "symbolic form" brought about, concomitantly placed man at a distance from the world, and gave him absolute control over the organisation of this newly conquered externality (Panofsky 66-72). It can be argued that this objectification of subjectivity, in the context of $19^{\text {th }}$ century imperialism, has cut off Western man from his own humanity within the world, and served to give rational legitimacy to his desires and greed. As this paper will attempt to show, this is the negative view of the Western perspective that the Australian writer of Aboriginal descent Kim Scott takes in his second novel, Benang (1999). The story, which is based very closely on Scott's research into his own genealogy, presents itself as a family 
history, researched and written by the narrator, Harley Scat, after he discovers that although white, he is of Aboriginal descent, and as such, has been mapped by his Scottish grandfather as the "first-white-man-born," a kind of racial vanishing point on the horizon of the New Australian Man. The narrator's initial aim in this family history, therefore, is to denounce the eugenicist policies in Australia, from the 1930s to 1950s, to exhibit himself as a kind of dead end, and thus to prove himself his grandfather's greatest failure. However, his quest into the past also enables him to discover narratives that contradict the archives, and other horizons of experience which enrich his own "narrative identity" (Ricœur 1990). Paul Ricœur opposes the notion of "narrative identity" to the substantialist definition of identity as sameness. He argues that personal identity is a narrative construct - a "concordant-discordant synthesis" (147) - integrating otherness into the configuration of the self. Narrative identity is a very useful analytical tool for the study of this novel which, ultimately, leads to a more meaningful definition of becoming than the one afforded by the colonial perspective of linear progress.

Scott's critical approach of Australian historiography through this piece of fiction is particularly relevant in the context of an ongoing national reconciliation, since most non-Aboriginal Australians were until quite recently unaware of the true nature of the colonisation of the continent. The resistance of Indigenous Australians was downplayed in history textbooks, and the myth of the "dying race" made it possible to gloss over the massacres, the deportations and the dispossessions in order to focus on the hardships suffered by the settlers. But in the 1930s, the growing number of so-called "half-castes" became of some concern to the authorities, particularly in Western Australia, where Scott's novel is set. A. O. Neville - who between 1915 and 1940 was the Chief Protector of Aborigines in Western Australia, then the Commissioner for Native Affairs - championed the alleged scientific theories according to which Aboriginal blood and colour could be absorbed and diluted into the white population by reasoned breeding, much like "a small stream of dirty water entering a larger clear stream." Neville denounced the dreadful conditions in the half-caste camps in which "human life spawns and increases like an unhealthy fungal growth," and called for the institutional and genetic assimilation that would, within a few generations, "[raise] the social and moral outlook of the coloured people generally - [instil] into them a sense of usefulness and desire to create homes in accordance with white standards." It was particularly important that half-caste children should be taken early from their parents lest these potential partners for whites "develop into weedy, undernourished semi-morons with the grave sexual appetites which characterise them." (Neville, 133, 182, 174 respectively) For the eugenicists, the fact that miscegenation between whites and Aborigines produced no sign of black atavism was proof that "the white race strongly asserts itself. The white colour overpowers the black." (Anderson, 229) In other words, these policies of absorption stood for what Warwick Anderson in The Cultivation of Whiteness calls a "reproductive frontier" which narcissistically served to confirm the superiority 
of the white man, while legitimating the predatory desires which Australia's hygienist society both repressed and exacerbated, thus conveniently conjuring up a vision of purified, triumphant whiteness on the horizon of the nation's future.

In the novel, the narrator's grandfather Ernest Solomon Scat as a young man, newly arrived from Scotland, and obsessed by his first sexual encounters with black women in the camps, is eager to apply the theories of Auber Neville who happens to be a distant relative of his. Having discovered these theories from Neville himself, and having seen how underfunded and understaffed the Chief Protector's department is, Scat sees these theories as a challenge: "It was as if he a little too late to be a pioneer, and not really cut out to tame the land - could still play a role in taming a people into submission." (32) By marrying successively two half-caste women, Ern Scat is thus able to cultivate his image as a progressive, tolerant man, while giving free rein to his sexual urges by abusing his wives, his successive maids, as well as the young girls and boys (among whom his son and grandson) he takes out of their orphanages and boarding schools for the holidays. Harley, the narrator, is unaware of the rational scientific "legitimisations" of his grandfather's desires, until, at the age of sixteen, he chances upon his own picture among Ern's notes, diagrams and photographs, and discovers that he is the result of his grandfather's experiments:

Captions to the photographs; full-blood, half-caste (first cross), quadroon, octoroon. There was a page of various fractions, possible permutations growing more and more convoluted. Of course, in the language of such mathematics it is simple; from the whole to the partial and back again. This much was clear; I was a fraction of what I might have been. [...] I saw my image inserted into sequences of three or four in which I was always at the end of the line (even now, I wince at such a phrase). (26)

The description calls to mind a photograph from Neville's book, Australia's Coloured Minority: Its Place in the Community (1947), which is not mentioned in the novel but was given some publicity after its appearance in Philip Noyce's film Rabbit Proof Fence (2002). When Harley discovers the pictures and notes, he is convalescing after a car-crash for which he was responsible, and in which he himself was castrated and his father died. His abusive grandfather has started calling him "Son," and has told him he should think of his father's death merely as "an unfortunate necessity." (24) This is when Harley discovers that Ern has planned him, long before he was even born, as a living proof of the annihilation of a whole side of his family, a whole people, and a whole culture: "It appeared that in the little family history my grandfather had bequeathed me options had disappeared. It seemed an inexorable process, this one of we becoming I. This reduction of a rich and variously shared place to one fragile, impoverished consciousness." (31) So his guilty self-hate turns into rebellion against his visionary creator, and he starts on a rival family history destined to show how all his grandfather's efforts have resulted in a pathetic failure, himself. As Lisa Slater writes in her article 
"Kim Scott's Benang: An Ethics of Uncertainty," Harley's position as an unhealthy post-colonial subject can be deployed as a weapon against colonial history and mythology (150).

Devised to denounce, contradict and derail the fiction of abstract progress, of a methodical, orderly process of absorption of the Indigenous population, Harley's version of his family history is disjointed, even chaotic to reveal mimetically the violence implied in the assimilationist reduction of Otherness to an idealized white identity-as-sameness. Just as the narrator wreaks havoc in his grandfather's study, throwing books, files and papers about, causing the old man to have an invalidating stroke; just as he carves "END, CRASH, FINISH" (445) into Ern's skin, out of frustration and anger at his place in his grandfather's story, the narrative sets out to bewilder and shock the reader. Victor Oost in his article "Benang and the Unbearable Whiteness of Being" questions this aggressive narrative strategy, and highlights the white reader's uncomfortable feeling that this aggressiveness is aimed particularly at him/her: "[D]oes the technique need to be as experimental, and the narrative voice as uncertain, in order to destabilise white readers?" (114)

Certainly, the narrative is structurally confusing, as the chronological order of events and generations that the reader would expect even in a fictitious family history is completely subverted. Although the narrator does begin with his grandfather's arrival and his "seminal" meeting with Neville, he soon introduces many other characters whose lives intersect his grandfather's, tracing back, little by little, his family line, or rather arborescence, up to his great-great-grand parents' generation, on the Aboriginal side. The storyline moves backwards and forwards in time with very few specific dates, sometimes resurrecting deceased characters at a different, significant moment in their lives. Moreover, Harley's history introduces repetition as a meaningful structural principle, thus contradicting the concept of linear progress: some events are represented several times either from different points of view to undermine an "official" perspective, or as a leitmotiv. For instance, the stench emanating from the corpse of a young Aboriginal boy left by the roadside, which is mentioned in the very first pages of the book (8) and again at the very end (481), is identified with "the smell of anxiety, of anger and betrayal" which recurs throughout the family history, and constitutes its dominant theme. As a framing motif to the novel, the black boy's reeking corpse offends both smell and sight by spoiling the view on the horizon of a white Australia.

Spatially, the colonial conquest of the land as represented by the confident railway lines vanishing into the secured distance is also contradicted by the constant, largely erratic circulation of Indigenous characters. They move from place to place, either because they are forcibly removed to native settlements, or because they have to flee from settler persecution, or else to try to find food and work, but sometimes also in order to try to re-establish contact with members of the family who were abducted, arrested or deported, or to try to recover meaningful connections with a now depleted and damaged land. Contrary to 
mainstream Australian novels, like Kate Grenville's The Secret River, that focus on white characters and give only occasional glimpses of Aboriginal characters drifting more and more meaninglessly about in the background, Harley's disjointed narrative chronicles the endurance of a spoliated people who still try to survive on their ancestral lands. Benang is also very different from Indigenous novels such as Sam Watson's fantasy The Kadaitcha Sung, or even Bruce Pascoe's historical novel Earth, insofar as it does not present the Indigenous populations as resistance fighters relying on a network of informers to counter a foreign invasion. Nevertheless, the narrator underscores the white administration's actual lack of control over the Aboriginal population, if only because Aborigines were not consistently registered until the 1967 census, and because the very definition of Aboriginality changed according to successive acts and amendments. Consequently, Aboriginal characters' names and identities tend to fluctuate in the narrative, due to the obtuse, contemptuously generic way they are referred to in official reports. For instance, Harley quotes from a series of letters and reports from different localities referring to sightings of a woman identified as Fanny Benang even though she is much younger than the Fanny Benang he has earlier identified as his seventy-year-old great-great-grandmother:

Fanny? It was really a no-name, a mean-nothing name. Not a name used to distinguish between people. We cannot depend on such names put down on paper. I think it was Dinah who had accepted what her mother bequeathed her and now had a baby in arms and a young girl walking at her side like a sister. But it may have been Fanny herself, rejuvenated by her escape [...]. Or perhaps, even, that the two of them had come together so close to their home to make yet another effort to keep the spirit they represented alive in the face of continuing betrayal. (103)

Even racial categories fluctuate and their ambiguity serves to subvert even more the doctrine of linear progress in which Ern Scat placed so much faith. For instance, in the very last pages of the book, the narrator's blond great-greatgrandfather, who had always been identified as a white man, is revealed to have had an Aboriginal grandmother. Five generations before Harley, therefore, there had already been a "first-white-man-born-in-the-family-line" so that Ern's founding experiment turns out to have been wholly irrelevant, even by his own standards:

How necessary, then, is it to acknowledge, let alone discuss, some very-first-whiteman? Well, to be fair, even if it took some time to arrive at me, there must have been some first-white-man involved. However, my grandfather was not firstanything, whatever he may have liked to think. He merely attempted to hasten things to their conclusion. The persistence, perhaps, of what he would have called the "spirit of empire."

A first white man is not the beginning of anything much. (456)

Harley criticises the colonial obsession with founding events that fix the history of a cultural group into an immutable identity, and that then legitimate the 
suppression of all other groups that might threaten this identity. He also writes against the empowering epistemological distance which is traditionally established between the historian and his material or, as in the citation below, between the police constable and his report, and helps sustain the fiction of objectified subjectivity:

Constable Hall... he would write.

This strange third person, always present with any writer and reader.

Whatever the intricacies of the writing and reading situation (Where and who were all these people when he re-read his own work?), it never failed to give him a particular joy to write Everything Correct and in Order. [...] These were lovely words. At such times it was a lovely world. (193)

Scott's narrator debunks such writing conventions by occasionally switching abruptly between first and third-person narration, as in the following passage where the prudishly euphemistic third-person is counted upon to do away conveniently with physical and psychological suffering:

I began, I believe, with how I found the seed of myself (but never, alas, my seed) in Grandfather's study. He had fallen ill. He fell. I did not push.

Ernest Solomon Scat fell seriously ill. He was not pushed. His grandson was staying with him, and was himself in convalescence, recovering from a serious accident in which... Well, it was not a happy time. His injuries were what, depending on your priorities, you might call superficial. That is to say, the damaged and missing parts were not at all large. (31)

Contrary to these distancing strategies, Harley's narrative is explicitly grounded in his own desperate need to write his family story, as an attempt to reconstruct his own depleted identity. Since, therefore, he begins his enquiry into the past with himself as the supposedly positive outcome of the eugenicist "plot," he is writing back against the end-orientated conception of time of post-Enlightenment historiography.

The reader's expectations are disappointed when instead of a clearly defined account of a family's history, he is faced with the narrator's obsessive quest for his own identity. At the beginning of his narrative, Harley literally exhibits himself as "this fuck-me-white and first one born. This drifting lightweight who so wanted to be his grandfather's failure. This (let me do away with all vanity) faceless, empty-scrotumed, limp-dicked first man born." (31) By presenting himself at the outset in this grotesque, obscene way, inscribing the suffering of his Aboriginal ancestors on the maimed and sterile body his family history has bequeathed him, Harley flies in the face of the eugenicists' obsession with purity. He blocks the perspective, and forbids access to the historian's rational, orderly, and disembodied account of the "larger picture." Throughout the novel, the carnivalesque body thus repeatedly asserts itself to subvert the language of power which resorts to metaphorical euphemisms to refer to its policies of assimilation. For instance, parodying the assimilationist metaphor stating that white civilisation would 
uplift and elevate Aborigines, Harley starts floating grotesquely about: "I closed my eyes, and when the crown of my head gently nudged the ceiling I must have looked like some elaborate light shade. Perhaps that was what my grandfather meant when he said I was brightest and most useful in an uplifted state." (13) He then proceeds to stage himself as the atavistically incompetent writer of this history, constantly calling the reader's attention to his failings as a narrator, thanking him for remaining with his "shifty, snaking narrative." (22) By placing himself so persistently in the foreground, the narrator blocks any possibility of taking the long, detached view expected of historiography. Thus, when writing about his father, and what he had to suffer at Ern's hands, the narrator ends up writing about the way in which his father's experience was interwoven in his own, and comments ironically: "But again, I digress and confuse all of us, one with the other. As if we were not all individuals, as if there were no such thing as progress or development, as if this history were just variations on the one motif." (367)

This kind of remark underlines the confrontational dimension of Scott's novel. The narrator's standpoint is made particularly clear when he pretends to fall for the fiction of the official view on the settlement of Western Australia, for instance when he ironically calls upon the reader to celebrate the entrepreneurial spirit of the landowners who claimed rations disproportionately from the Aborigines department and used them as wages:

I would like you to consider the initiative we see demonstrated here, in these letters of the forefathers; the pioneering, entrepreneurial and opportunistic spirit which soars when there is money to be gained. The initial lease cost them nothing, and the purchase and exchange of rations provides a necessary stimulant to the economy they are creating. (207)

Here the reader is directly asked to reconsider the basis of colonial liberalism, and must therefore relinquish the comfortable, passive position assigned him by the traditional reader's pact equally valid within the frameworks of both the novel and the historical text. But if the implicit reader is brought out of his reserve by the narrator's summons, the question arises as to how he, the reader, is constructed. Is he black, or white; is he to be identified with the victims or the perpetrators of colonialism? However, if the novel were indeed raising such questions, it would mean Scott was resuscitating the racist discourse in reverse, which would clearly be counterproductive. Besides, on what moral grounds of ethnic authenticity would the narrator be entitled to position himself as the representative of Indigenous people? As the other protagonists keep telling Harley, he looks very much like his grandfather who remains "family" in spite of everything, and they insist that he cannot simply dispense with him, as Ern has tried to do with the Aboriginal members of the family. The narrator's very hybridity, therefore, is a means to avoid the pitfalls associated with a less ambiguous definition of his identity. The fact that he descends both from white and Aboriginal ancestors gives a new meaning to the concept of "family" and to the sense of betrayal which is so dominant in 
the novel. Betrayal implies a former understanding, a trust however tacit between members of a group. Indeed, the body of the young boy left by the wayside that accompanies the narrator's ancestors into the story at the beginning of the novel is identified at the end as "the returned body of Johnny Forrest, namesake of the Premier. Grandchild of the Premier who had promised much, but forsaken his family." (481) Rape or neglect are therefore no longer presented as anonymous, random acts of aggression which force individual Indigenous women and children into the position of the victimised Other, but as a global refusal of the white community (as represented by Sir John Forrest (1847-1918) who was an Australian explorer, and later became the first Premier of Western Australia and a cabinet minister in Australia's first Federal Parliament) to assume responsibility for, and to extend true protection to fellow Australians. In an effort to redeem this ethical failure, the narrator acknowledges how impossible it is to dissociate the betrayed "we" from the betraying "them":

Searching across the archives I have come across photographs of ancestors which have been withdrawn from collections, presumably because evidence of a too-dark baby has embarrassed some descendent or other.

My family, my people, we have done such things. Shown such shame and selfhatred. It is hard to think what I share with them, how we have conspired in our own eradication. (97-98)

This does not mean that the victims of the past should be confused with their persecutors, but that their descendents should be aware that their own identity is made up of different, sometimes conflicting narratives. Trying to identify himself in the mirror, the narrator is assailed by all the clichéd identities projected upon Aborigines by white narratives:

Hovering before a mirror, I saw a stranger. [...] The image shifted, and changed shape [and] it was terrible to see the shapes, the selves I took.

I stood motionless against a setting sun; posture perfect, brow noble, features fine.

Saw myself slumped, grinning, furrow-browed, with a bottle in my hand.

Was Tonto to my grandfather's Lone Ranger. Guran to some Phantom.

There appeared a footballer, boxer, country and western singer.

A tiny figure, sprawled on the ground in some desert landscape, dying. (12)

All these narratives, which Harley has integrated along with a "white" education, are supposed to have "uplifted" and elevated him, as we saw before (13), by cutting him off effectively from his ancestors' Aboriginal narratives. But with a touch of magic-realism, Neville's metaphor is literalised and Harley finds that his tendency to float about in the air also enables him to discover new vertical perspectives as opposed to merely horizontal ones:

I rose and fell on currents of air like a balloon, like a wind-borne seed. The horizon moved away so that the islands no longer rested on its line, but stood within 
the sea, and it seemed that the pulsing white at the island's tip was not a mere transformation induced by collision, but was a blossoming and wilting at some fissure where sea met land. (163-64)

Ironically, the cultural near-death and the rootlessness which the eugenicist lie has inflicted on him also brings out in him a capacity for levitation that gives him an aerial perspective characteristic of Aboriginal spiritual vision. This is how he becomes capable of discovering a dynamic unity and continuity beyond the apparent conflict. As an educated, "bleached" black man who has access to the archives but also to the narratives of some of his surviving Aboriginal relatives, Harley is able to imagine or remember the narratives of his ancestors, and finally to acknowledge the underlying presence of the many stories, even his grandfather's, within what one might call, to borrow from Paul Ricœur, his own "narrative identity" (Ricoeur 147).

The indeterminate position of the narrator changes the nature of the address to the reader: it is no longer a question of confirming a similarity or a difference of views, but of establishing the kind of dialogue Lisa Slater refers to as the ethical moment: "The exposure to the other reveals the radical social construction of our self; indeed, that we are reliant on the other for our self. Hence, the ethical moment ruptures the self from self-understanding and causes anguish." (Slater 148)

Certainly, in Benang, this dialogue between the narrator and the reader is not a comfortable one. With the incipit of the novel, entitled "from the heart," the reader is forewarned that $s /$ he must be prepared to give up ideological and cultural assumptions to listen to Harley's disturbing narrative: "I know I make people uncomfortable, and embarrass even those who come to hear me sing." (7) In the very last pages of the novel, the narrator again addresses his readers, leaving open the interpretations of the final personal pronoun:

I acknowledge that there are many stories here, in the ashes below my feet - even my grandfather's. [...] I offer these words, especially to those of you I embarrass, and who turn away from the shame of seeing me; or perhaps it is because your eyes smart as the wind blows the smoke a little toward you, and you hear something like a million million many-sized hearts beating, and the whispering of waves, leaves, grasses...We are still here, Benang. (495)

"Benang" is Harley's Aboriginal family name and has been translated in the novel as "tomorrow." This "tomorrow" can be read as a threat if the reader chooses to understand "we" as referring only to Aborigines, and thus remains trapped in the paranoid fear of a fantasy Other. Or it can be interpreted as a promise, if he accepts being included in the enlightened discourse resulting from the paradigmatic layering of narratives which the novel has tried to establish. Whatever the reader's decision may be, in this novel Scott clearly resists the notion that modern Australia should just forget about the past, and "move on" towards the future. For Scott as for other Indigenous writers, access to a valid future can only be gained after having resuscitated the past, and for him, fiction is a means to re-establish a 
dialogue in order to pave the way towards wider and more encompassing social and cultural horizons, and a more ethical definition of Australian identity.

Anne LE GUELLEC

Université de Brest

\section{Works Cited}

Anderson, Warwick. The Cultivation of Whiteness: Science, Health, and Racial Destiny in Australia. Durham: Duke UP, 2006.

Grenville, Kate. The Secret River. Edinburgh: Canongate, 2006.

Neville, A. O. Australia's Coloured Minority: Its Place in the Community. Sydney: Currawong, 1947.

Noyce, Philip, dir. The Rabbit-Proof Fence. Miramax Films, 2002.

Oost, Victor. "Benang and the Unbearable Whiteness of Being: Kim Scott's Family Narrative and Prospects for Reconciliation." Cultures of the Commonwealth 14 (Winter 2007-8): 107-19.

Panofsky, Erwin. Perspective as Symbolic Form. Trans. Christopher Wood. New York: Zone, 1997.

Pascoe, Bruce. Earth. Broome: Magabala, 2001.

Ricceur, Paul. Oneself as Another. Trans. Kathleen Blamey. Chicago: U of Chicago P, 1992.

Scotт, Kim. Benang: From the Heart. Freemantle: Freemantle Arts Center, 1999.

Slater, Lisa. "Kim Scott's Benang: An Ethics of Uncertainty." Journal of the Association for the Study of Australian Literature 4 (2005): 147-158.

Watson, Sam. The Kadaitcha Sung. Ringwood: Penguin Australia, 1990. 